\title{
Selective sorption of uranium from aqueous solution by graphene oxide-modified materials
}

\author{
H. Mohamud',2 P. Ivanov' ${ }^{2}$ B. C. Russell ${ }^{2}$ P. H. Regan ${ }^{2,3} \cdot$ N. I. Ward ${ }^{1}$
}

Received: 30 September 2017 / Published online: 17 February 2018

(C) The Author(s) 2018. This article is an open access publication

\begin{abstract}
The effect of competing ions on the sorption behaviour of uranium onto carboxyl-functionalised graphene oxide $(\mathrm{COOH}-$ GO) were studied in batch experiments in comparison to graphene oxide (GO) and graphite. The effect of increasing the abundance of select chemical functional groups, such as carboxyl groups, on the selectivity of U sorption was investigated. In the course of the study, $\mathrm{COOH}-\mathrm{GO}$ demonstrated superior performance as a sorbent material for the selective removal of uranyl ions from aqueous solution with a distribution coefficient of $3.72 \pm 0.19 \times 10^{3} \mathrm{~mL} \mathrm{~g}^{-1}$ in comparison to $3.97 \pm 0.5 \times 10^{2}$ and $2.68 \pm 0.2 \times 10^{2} \mathrm{~mL} \mathrm{~g}^{-1}$ for GO and graphite, respectively.
\end{abstract}

Keywords Sorption $\cdot$ Uranium $\cdot$ Carboxyl-functionalised graphene oxide $\cdot$ Selectivity $\cdot$ ICP-MS

\section{Introduction}

Uranium belongs to the actinide series and has three naturally occurring radioisotopes: ${ }^{238} \mathrm{U}\left(T_{1 / 2}=4.468 \times 10^{9} \pm\right.$ $0.005 \mathrm{y}),{ }^{234} \mathrm{U}\left(T_{1 / 2}=2.455 \times 10^{5} \pm 0.006 \mathrm{y}\right)$ and ${ }^{235} \mathrm{U}$ $\left(T_{1 / 2}=7.1 \times 10^{8} \pm 0.011 \mathrm{y}\right)$ with an average abundance of $2.4 \mathrm{mg} \mathrm{kg}^{-1}$ in the Earth's crust $[1,2]$. The high prevalence of uranium and its radiotoxicity makes it a vital radionuclide to monitor in the environment [3]. Furthermore, numerous studies have highlighted the importance of developing rapid and effective treatment processes for aqueous nuclear waste produced in activities related to the nuclear fuel cycle [4-6]. Existing treatment processes, which are currently used at an industrial scale to remove uranium from aqueous nuclear waste commonly involve ion-exchange, co-precipitation and

Electronic supplementary material The online version of this article (https://doi.org/10.1007/s10967-018-5741-4) contains supplementary material, which is available to authorized users.

H. Mohamud

h.mohamud@surrey.ac.uk

1 Department of Chemistry, University of Surrey, Guildford GU2 7XH, UK

2 National Physical Laboratory, Hampton Road, Teddington TW11 OLW, UK

3 Department of Physics, University of Surrey, Guildford GU2 7XH, UK solvent extraction [7-10]. However, these processes typically exhibit low selectivity when their distribution co-efficients $\left(K_{\mathrm{d}}\right)$ are reported. Moreover, they often display slow sorption kinetics for target long-lived radionuclides, especially in the presence of competing ions [11]. Thus, alternative techniques capable of selective and rapid removal of uranium from aqueous solution would be of significant value.

One such technique is sorption which has been widely used due to its ease of operation, simplicity and limited use of solvents [12]. Recent studies have demonstrated that nanomaterials, specifically graphene oxide (GO), outperform traditional sorbent materials, such as bentonite and activated carbon, by exhibiting higher loading capacities and efficiencies for uranium removal [13]. This is believed to be due to the exceptional intrinsic properties of GO, including an extremely high contact surface, plus a wide range of chemical functionalities $[14,15]$. As a result, the presence of selective surface functional groups on GO, such as, carboxyls and hydroxyls, enable for the sorption of uranyl species through surface complexation [16]. This has been demonstrated by Li et al. who have reported the use of GO for uranium removal and determined the maximum sorption capacity to be $299 \mathrm{mg} \mathrm{g}^{-1}$ at $\mathrm{pH} 4$ [17]. The efficiency of GO for uranium removal has been found to be improved by the addition of larger chelating ligands on the surface of GO. For instance, Wang et al. have shown functionalising GO with amidoxime led to an increased 
sorption capacity of $398.4 \mathrm{mg} \mathrm{g}^{-1}$ at $\mathrm{pH} 6$ [18]. In addition, selectivity for uranium removal was found to be enhanced in comparison to GO when the material was exposed to simulated seawater comprising of $\mathrm{Mg}, \mathrm{Ca}, \mathrm{Ba}$ and $\mathrm{Sr}$ [18]. Therefore, these results demonstrate the effectiveness of both GO and surface-modified GO for uranium removal. Furthermore, such studies also illustrate the need for additional investigation into the effect of increasing the abundance of complexing groups, such as carboxyls, on the selective removal of uranium.

The aim of this study is to synthesise carboxyl-functionalised graphene oxide materials (COOH-GO) designed with a high affinity towards the sorption of long-lived actinides, focusing on uranium. The sorption behavior of $\mathrm{COOH}-\mathrm{GO}$ was investigated and compared to GO and graphite, in the form of batch sorption studies, which included studying the effect of $\mathrm{pH}$, contact time and competing ions prior to inductively coupled plasma mass spectrometry (ICP-MS) analysis. Moreover, each of the sorbent materials were further analysed using a series of surface characterisation techniques, such as Fourier transform infrared spectroscopy and Raman spectroscopy. In addition, thermogravimetric analysis and a methylene blue colourimetric assay were performed to attain a full characterisation profile of each material to assess their suitability for use in radionuclide sorption, waste processing and immobilisation.

\section{Experimental}

\section{Reagents and materials}

All chemical reagents used were of analytical grade and purchased from Sigma Aldrich (Poole, UK). As-received natural graphite flakes $(<45 \mu \mathrm{m}$, grade 230 , Asbury Graphite Mill Ltd) were used as the starting material to prepare graphene oxide (GO). For ICP-MS measurements, a $100 \mathrm{mg} \mathrm{mL}^{-1}$ stock standard solution of uranium in $2 \%$ $\mathrm{HNO}_{3}$ (Fisher Scientific, Loughborough, UK) and multielement standard (MES) solution (Fisher Scientific, Loughborough, UK) containing $5000-20,000 \mu \mathrm{g} \mathrm{mL}{ }^{-1}$ of $\mathrm{Mg}, \mathrm{Co}, \mathrm{Zn}, \mathrm{Sr}, \mathrm{Pb}$, Th and $\mathrm{U}$ in $2 \% \mathrm{HNO}_{3}$ were used (see Table S1). Solutions were diluted with ultrapure deionised (DI) water obtained using an ELGA purelab flex water purification system (ELGA, Veolia Water, Marlow, UK, $18 \mathrm{M} \Omega \mathrm{cm},<5 \mathrm{ppb}$ Total Organic Carbon). The pH was measured with a digital pH/ISE meter (Orion Star A214, Thermo Scientific, UK)

\section{Preparation of GO}

GO was synthesised from natural graphite according to the modified Hummers method [19-21]. Briefly, $1 \mathrm{~g}$ of graphite was added to $120 \mathrm{~mL}$ of sulphuric acid $\left(\mathrm{H}_{2} \mathrm{SO}_{4}\right.$, $98 \%)$ and $0.5 \mathrm{~g}$ of sodium nitrate $\left(\mathrm{NaNO}_{3}, 99 \%\right)$, which was continuously stirred on a magnetic hot plate at $300 \mathrm{rpm}$ for $1 \mathrm{~h}$ and cooled to $20^{\circ} \mathrm{C}$ using a water bath. Next, $6 \mathrm{~g}$ of potassium permanganate $\left(\mathrm{KMnO}_{4}, 99 \%\right)$ was slowly added and the resulting mixture was left to stir overnight at $35{ }^{\circ} \mathrm{C}$. A solution of $10 \mathrm{~mL}$ of hydrogen peroxide $\left(\mathrm{H}_{2} \mathrm{O}_{2}, 35 \%\right)$ in $400 \mathrm{~mL}$ of ice was next added resulting in a bright yellow precipitate.

For work-up, the remaining precipitate was collected, diluted with $500 \mathrm{~mL}$ of $0.5 \mathrm{M}$ hydrochloric acid $(\mathrm{HCl}$, 99\%) solution and purified by repeated washing with DI water and centrifugation $(4000 \mathrm{rpm}, 20 \mathrm{~min})$ until the $\mathrm{pH}$ of the supernatant was neutral. To achieve nano-sized flakes of GO, a series of sonication treatments with an ultrasonic bath (Ultrawave U300H) were completed for $1 \mathrm{~h}$ and the resulting product was freeze-dried to obtain graphene oxide.

\section{Preparation of $\mathrm{COOH}-\mathrm{GO}$}

COOH-GO was synthesised by reducing the hydroxyl groups present in GO to carboxyl groups [22, 23]. In a typical procedure, $0.05 \mathrm{~g}$ of $\mathrm{GO}$ in $50 \mathrm{~mL}$ of DI water was sonicated for $30 \mathrm{~min}$. Next, $1.2 \mathrm{~g}$ of chloroacetic acid $\left(\mathrm{ClCH}_{2} \mathrm{COOH}, 99 \%\right)$ and $1 \mathrm{~g}$ of sodium hydroxide $(\mathrm{NaOH}$, 99\%) were added to the GO solution and sonicated for $3 \mathrm{~h}$. The resulting black $\mathrm{COOH}-\mathrm{GO}$ mixture was neutralised with $0.5 \mathrm{M} \mathrm{HCl}$ solution and purified by repeated washing with DI water and centrifugation (2000 rpm, $10 \mathrm{~min})$. Finally, the resulting product was freeze-dried to obtain carboxylated graphene oxide.

\section{Characterisation techniques}

Figure 1 shows the proposed structure of the materials under investigation. Structural analysis was completed by characterising the samples by Fourier transform infrared spectroscopy (FTIR) and Raman spectroscopy. FTIR spectra of solid powdered samples were recorded on a Cary 670 FTIR spectrometer using attenuated total reflectance (Agilent Technologies, UK). Raman spectra of all samples were obtained on a DXR high resolution Raman microscope (Thermo Scientific, UK) equipped with an Ar laser (irradiation wavelength $532 \mathrm{~nm}, 10 \mathrm{~mW}$ laser power, $0.7 \mu \mathrm{m}$ spot size, $\times 50$ microscope objective, $10 \mathrm{~s}$ collection exposure, 32 scans) and an average of three sample spots were selected for study with the data collected analysed using OMNIC $^{\mathrm{TM}}$ software. Elemental analysis was conducted on a CE440 elemental analyser (Exeter Analytical, USA). Thermal analysis was obtained by thermogravimetric analysis (TGA) and was carried out on a TGA Q500 (TA Instruments, USA). Samples were placed 
into platinium crucibles $(1-2 \mathrm{mg}$ ) and heated from ambient temperature to $900{ }^{\circ} \mathrm{C}$ at a heating rate of $10{ }^{\circ} \mathrm{C} \mathrm{min}-1$ under a $\mathrm{N}_{2}$ gas flow.

\section{Methylene blue assay}

The quantification of the total abundance of carboxyl groups functionalised to graphite, $\mathrm{GO}$ and $\mathrm{COOH}-\mathrm{GO}$ was determined by the published method of Imani et al. and involved the use of a colorimetric-based assay with the dye molecule methylene blue (MB) [24, 25]. Initially, a standard calibration curve of aqueous $\mathrm{MB}$ solutions $\left(0.2-5 \mu \mathrm{g} \mathrm{mL}^{-1}\right)$ was prepared and recorded at $664 \mathrm{~nm}$ in $0.1 \mathrm{M}$ sodium bicarbonate $\left(\mathrm{NaHCO}_{3}, 99 \%\right)$ buffer at $\mathrm{pH} 8$. Next for a typical MB assay, $2 \mu \mathrm{g} \mathrm{mL}^{-1}$ of aqueous MB solution was added to $5 \mathrm{mg}$ of graphite, graphene oxide and carboxylated graphene oxide, respectively and incubated for $15 \mathrm{~min}$. After centrifugation for $5 \mathrm{~min}$ at $4500 \mathrm{rpm}, 1 \mathrm{~mL}$ of the supernatant was collected and then analysed via UV-vis spectrophotometry (Biochrom Libra S80, UK) with the absorbance recorded at $664 \mathrm{~nm}$.

\section{Batch sorption experiments}

The sorption of $\mathrm{U}$ onto graphite, $\mathrm{GO}$ and $\mathrm{COOH}-\mathrm{GO}$ materials was investigated in batch experiments as ilustrated in Fig. 2. To test the effect of $\mathrm{pH}$, a series of $10 \mathrm{~mL}$ $\mathrm{U}$ solutions $\left(10 \mu \mathrm{g} \mathrm{mL}^{-1}\right)$ were prepared in $15 \mathrm{~mL}$ centrifuge tubes, which were $\mathrm{pH}$ adjusted from $\mathrm{pH}$ 1-13 with 0.01-1.00 M solutions of $\mathrm{HNO}_{3}$ and $\mathrm{NaOH}$, respectively. For contact time studies, the $\mathrm{pH}$ was adjusted to $\mathrm{pH} 4$ with $0.01 \mathrm{M} \mathrm{HNO}_{3}$ and timed aliquots were collected from 5 to $140 \mathrm{~min}$. In a typical sorption experiment, an initial aliquot was taken of the prepared solutions to determine the initial concentration of $\mathrm{U}$. This was then subsequently followed by the addition of $10 \mathrm{mg}$ of sorbent material to the $\mathrm{pH}$ adjusted suspensions. The samples were shaken, left for $24 \mathrm{~h}$ to equilibrate and a final sample aliquot was collected.

To test the effect of competing ions, the sorption experiment was repeated with $10 \mathrm{~mL}$ of diluted multielement standard (MES) solutions (see Table S1) at pH 4.
The U and MES concentrations in both the initial and final aliquots collected for the single and multi-component batch studies were analysed using an inductively coupled plasma mass spectrometer (ICP-MS) (Agilent 8800, Agilent Technologies, UK) [26]. The instrument was fitted with a quartz double-pass spray chamber and a MicroMist nebuliser (Glass Expansion, Melbourne, Australia) and nickel sample and skimmer cones (Crawford Scientific, South Lanarkshire, UK). The instrument was tuned daily using a mixed $1 \mu \mathrm{g} \mathrm{mL}^{-1}$ standard tuning solution.

The percentage of $U$ and other elements of interest sorbed onto graphite, GO and $\mathrm{COOH}-\mathrm{GO}$ in the batch studies was determined by Eq. (1) with the corresponding distribution co-efficient, $K_{\mathrm{d}}$, determined by Eq. (2).

Sorption $(\%)=100-\left(\frac{\text { CPSf }}{\text { CPSi }}\right) \times 100$

$K_{\mathrm{d}}\left(\mathrm{mLg}^{-1}\right)=\left(\frac{\mathrm{CPSi}-\mathrm{CPSf}}{\mathrm{CPSf}}\right) \times\left(\frac{V}{m}\right)$

where CPSi refers to the initial counts per second detected prior to the addition of the sorbent sample by ICP-MS, and CPSf refers to the final counts per second detected. $V$ refers to the volume of standard solution used (U or MES) in $\mathrm{mL}$ and $m$ refers to the mass of sorbent material used in $\mathrm{mg}$.

\section{Results and discussion}

\section{Structural analysis}

FTIR spectroscopy was used to identify key surface functional groups present in graphite, $\mathrm{GO}$ and $\mathrm{COOH}-\mathrm{GO}$. As depicted in Fig. 3a, graphite had no significant characteristic absorption peaks identified.

GO exhibited characteristic absorption peaks at $3407.3 \mathrm{~cm}^{-1}$ due to $\mathrm{O}-\mathrm{H}$ stretching. Moreover, $\mathrm{C}=\mathrm{O}$ stretches and $\mathrm{C}-\mathrm{O}-\mathrm{C}$ stretches were found at the following adsorption bands, 1733.2 and $1027.8 \mathrm{~cm}^{-1}$, respectively $[27,28]$. Further treatment of GO with chloroacetic acid led to the introduction of a new $\mathrm{COOH}$ adsorption band at $1644 \mathrm{~cm}^{-1}$ [24]. The discovery of this new adsorption
Fig. 1 The proposed chemical structures of a graphite, $\mathbf{b}$ GO and $\mathbf{c} \mathrm{COOH}-\mathrm{GO}[20,22]$ (a)

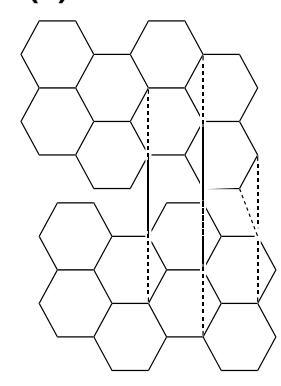

(b)

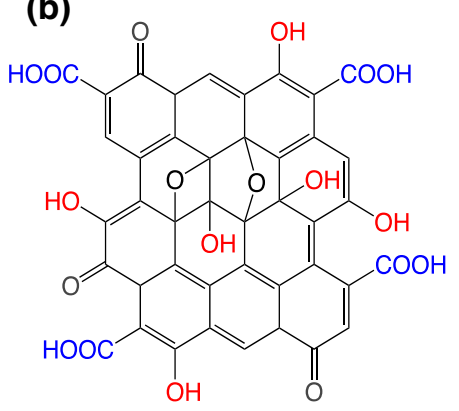

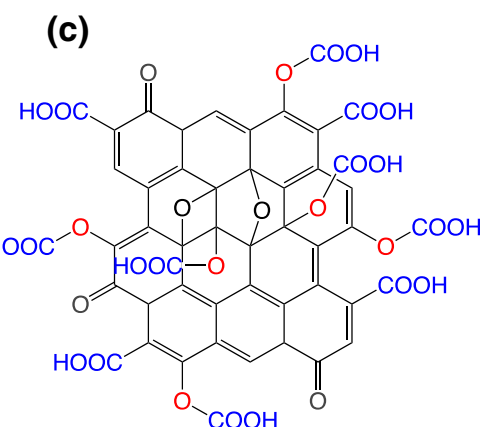


Fig. 2 Schematic representation of the single-component batch studies completed for the sorption of U onto graphite, GO and $\mathrm{COOH}-\mathrm{GO}$
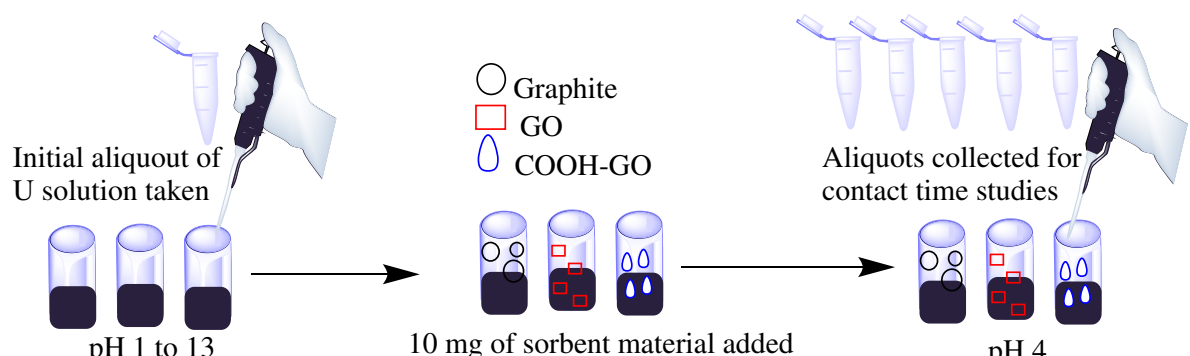

$10 \mathrm{mg}$ of sorbent material added contact time studies

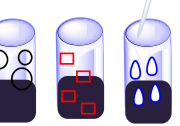

$\mathrm{pH} 4$
ICP - MS analysis of all aliquots collected
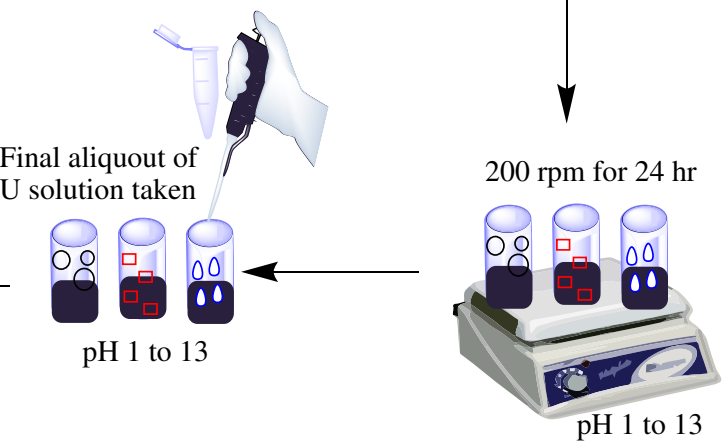

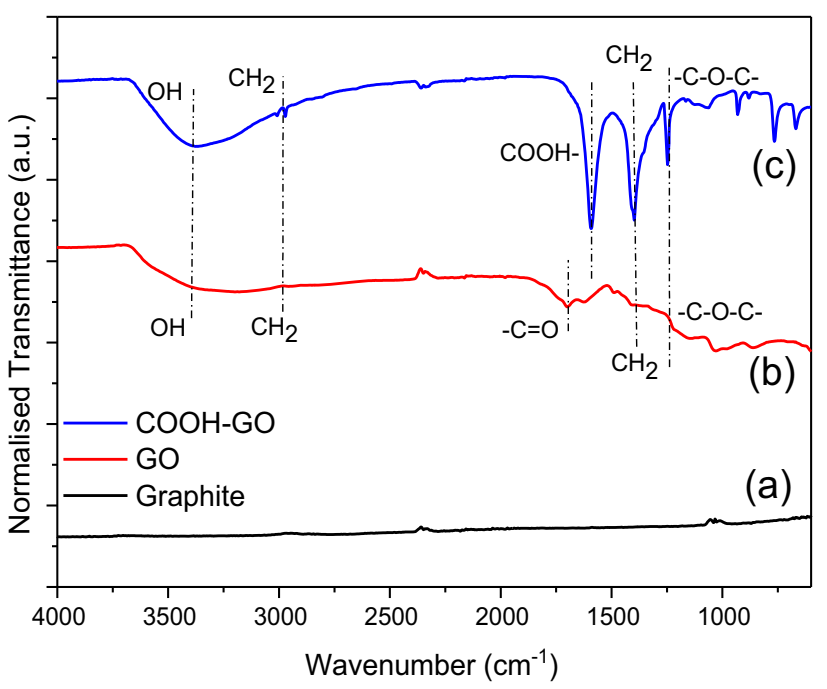

Fig. 3 Surface functionalities identified onto a graphite, b GO and c COOH-GO samples by FTIR spectroscopy

band in conjuction with an enhanced $\mathrm{O}-\mathrm{H}$ absorption peak at $3320.3 \mathrm{~cm}^{-1}$ demonstrates the successful introduction of a greater abundance of $\mathrm{COOH}$ groups to the surface of graphene oxide to produce $\mathrm{COOH}-\mathrm{GO}$.

Raman spectroscopy is a common technique used to analyse carbon-based materials e.g., carbon nanotubes, graphene and fullerenes $[29,30]$. In this study, the technique was used to compare the varying degree of functionalisation attributed to graphite, to that of as-prepared $\mathrm{GO}$ and $\mathrm{COOH}-\mathrm{GO}$ (Fig. 4b, c) [31]. In addition, the intensity ratio between the $\mathrm{D}$ and $\mathrm{G}$ band $\left(\mathrm{I}_{\mathrm{D}} / \mathrm{I}_{\mathrm{G}}\right)$ was also evaluated to monitor the number of $\mathrm{sp}^{2}$ i.e., aromatic domains present in the samples [32, 33]. The Raman spectra of GO and $\mathrm{COOH}-\mathrm{GO}$ showed the presence of two characterisitc bands associated with aromatic hydrocarbon materials: a strong signal for the D band at 1350.6 and $1348.8 \mathrm{~cm}^{-1}$, plus an intense signal for the $\mathrm{G}$ band at 1585.6 and $1578.5 \mathrm{~cm}^{-1}$, respectively.

The increase in signal observed in the D band for GO and $\mathrm{COOH}-\mathrm{GO}$ indicates the successful transformation of the $\mathrm{sp}^{3}$ domains, typically present in graphite, into $\mathrm{sp}^{2}$ domains [33]. The corresponding $\mathrm{I}_{\mathrm{D}} / \mathrm{I}_{\mathrm{G}}$ ratios also confirms

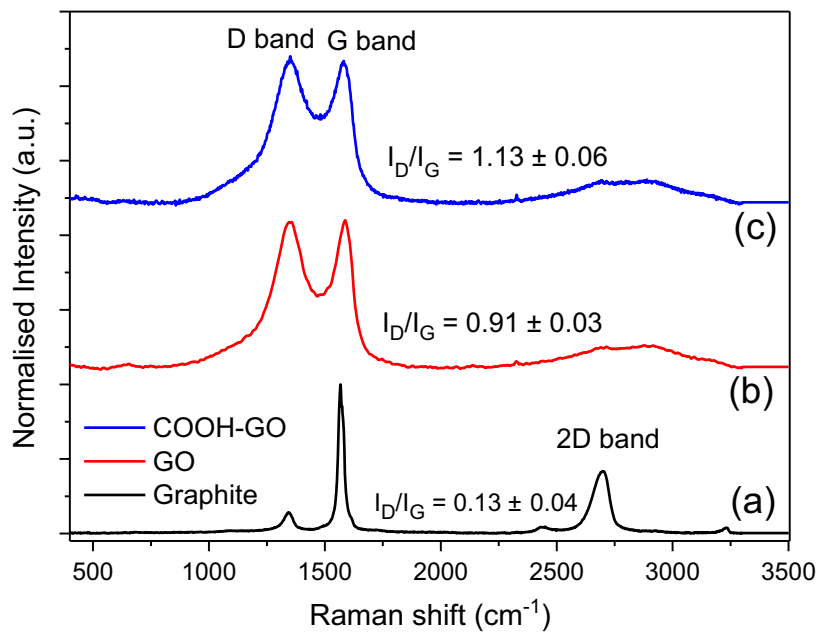

Fig. 4 Raman spectra of $\mathbf{a}$ graphite, $\mathbf{b}$ GO and $\mathbf{c} \mathrm{COOH}-\mathrm{GO}$ with their corresponding $\mathrm{I}_{\mathrm{D}} / \mathrm{I}_{\mathrm{G}}$ ratios. Values reported as mean $\pm \mathrm{SD}$ where $n=3$ 
this finding with the value increasing from $0.13 \pm 0.04$ for graphite to $0.91 \pm 0.03$ and $1.13 \pm 0.06$ for $\mathrm{GO}$ and $\mathrm{COOH}-\mathrm{GO}$, respectively. Thus, demonstrating the effective introduction of new surface chemical functional groups to $\mathrm{GO}$ and $\mathrm{COOH}-\mathrm{GO}$.

\section{Thermal analysis}

Thermogravimetric analysis (TGA) was used to determine the thermal stability of graphite, GO and $\mathrm{COOH}-\mathrm{GO}$. Figure $5 \mathrm{a}$ illustrates the exceptional thermal stability of graphite with minimal weight loss observed after thermal treatment to $900{ }^{\circ} \mathrm{C}[34,35]$. The TGA plot of GO indicates that its thermal decomposition occurs primarily through a three-step process $[20,36]$. Initially, minimal weight loss is observed from ambient temperature to $130{ }^{\circ} \mathrm{C}$ due to the loss of water. This is then followed by a second loss from 180 to $280{ }^{\circ} \mathrm{C}$, which is attributed to the loss of oxygen containing functional groups, such as, hydroxyl and carboxyl groups.

Finally, the third decomposition step observed was from 400 to $790{ }^{\circ} \mathrm{C}$, which was due to the loss of the carbonyl groups present in the $\mathrm{sp}^{2}$ carbon network. Figure $5 \mathrm{c}$ shows the TGA plot of COOH-GO and illustrates that its thermal decomposition occurs through a similar mechanism as that for GO. However, a sharper loss was observed from 180 to $280{ }^{\circ} \mathrm{C}$, which implies that a greater number of oxygencontaining functional groups, such as, carboxyl groups are present in $\mathrm{COOH}-\mathrm{GO}$. This finding agrees well with the reported literature and illustrates the success of the chloroacetic acid/ $\mathrm{NaOH}$ treatment in introducing carboxyl groups to the surface of the COOH-GO material [37].

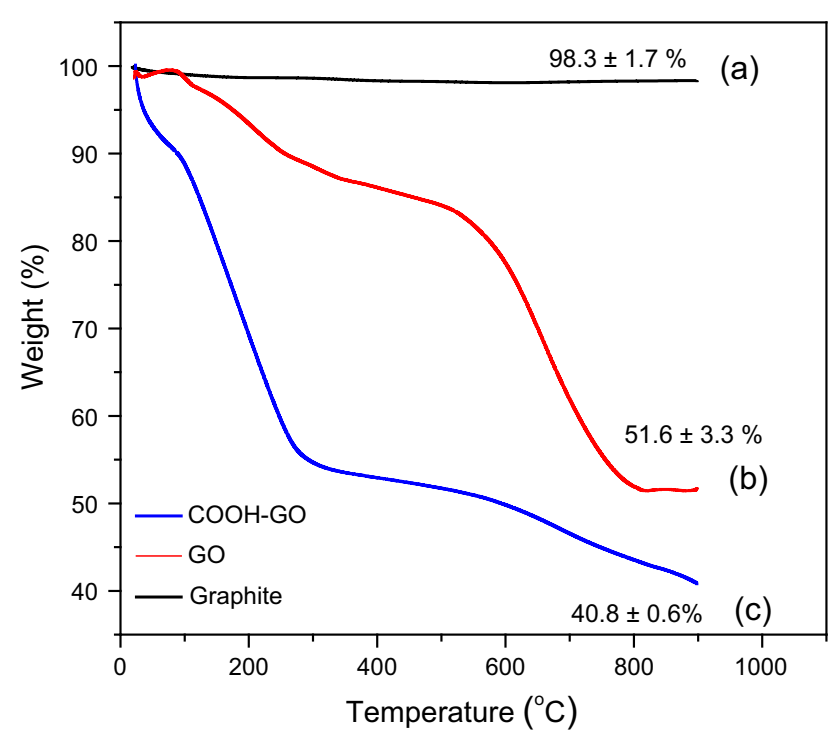

Fig. 5 TGA plots of a graphite, $\mathbf{b}$ GO and $\mathbf{c} \mathrm{COOH}-\mathrm{GO}$

\section{Quantitative analysis of carboxyl groups}

A methylene blue (MB) colourimetric assay was performed to quantitatively determine the carboxyl content of graphite, GO and COOH-GO (Fig. 6). The assay works on the principle that methylene blue reduces to leucomethylene blue in the presence of samples containing $\mathrm{COOH}$ groups [24]. This results in a colour change, which can be monitored by UV-vis spectrophotometry. As a result, the total amount of $\mathrm{COOH}$ groups $\left(\mu \mathrm{mol} \mathrm{mg}^{-1}\right.$ ) present in each sample was determined by measuring the absorbance value of the sample after the addition of MB and comparing that to the absorbance value recorded for the reagent blank $\left(2 \mu \mathrm{g} \mathrm{mL}^{-1}\right)$.

Table 1 highlights the results for the elemental analysis and the MB assay of graphite, $\mathrm{GO}$ and $\mathrm{COOH}-\mathrm{GO}$. The results showed that, for each sample preparation procedure, the $\mathrm{COOH}$-content increased from $0.0006 \pm 0.0002$ $\mu \mathrm{mol} \mathrm{mg}{ }^{-1}$ for graphite to $0.103 \pm 0.003 \mu \mathrm{mol} \mathrm{mg} \mathrm{m}^{-1}$ for COOH-GO. This data supports the experimental results obtained for the other complementary characterisation techniques i.e., FTIR and TGA analysis.

\section{Uranium sorption studies}

\section{Effect of $\mathrm{pH}$}

Solution acidity can strongly affect radionuclide speciation and therefore has a significant impact on the sorption process and efficiency of the sorbent materials. Thus, for this study, the effect of $\mathrm{pH}$ on the retention of $\mathrm{U}$ by graphite, $\mathrm{GO}$ and $\mathrm{COOH}-\mathrm{GO}$, was evaluated over a $\mathrm{pH}$ range from 1 to 13 (Fig. 7a, b). The general trend observed for the three sorbent materials, was for increased $U$ sorption between $\mathrm{pH} 2$ and 11, which is consistent with data previously reported $[38,39]$.

Of particular note is the trend observed at $\mathrm{pH} 1$, with the $K_{\mathrm{d}}$ values $\left(\mathrm{mL} \mathrm{g}^{-1}\right)$ and sorption $(\%)$ attained for $\mathrm{U}$ increasing in the following order for the sorbent materials investigated: $\mathrm{COOH}-\mathrm{GO}>\mathrm{GO}>$ graphite. This suggests that the presence of carboxyl groups had an impact on $\mathrm{U}$ sorption at significantly low $\mathrm{pH}$ levels. This is most likely due to the negatively charged surface of $\mathrm{COOH}-\mathrm{GO}$ and GO [40] initiating electrostatic interactions with the positively charged $\mathrm{U}(\mathrm{VI})$ species, $\mathrm{UO}_{2}{ }^{2+}$, typically found in solution at low $\mathrm{pH}$ which has been reported by Xie et al. [38].

In contrast, at $\mathrm{pH} 10$ and higher, it was observed that the performance of all three sorbent materials decreased considerably. This was believed to be due to the formation of negatively charged and stable uranyl carbonate complexes 

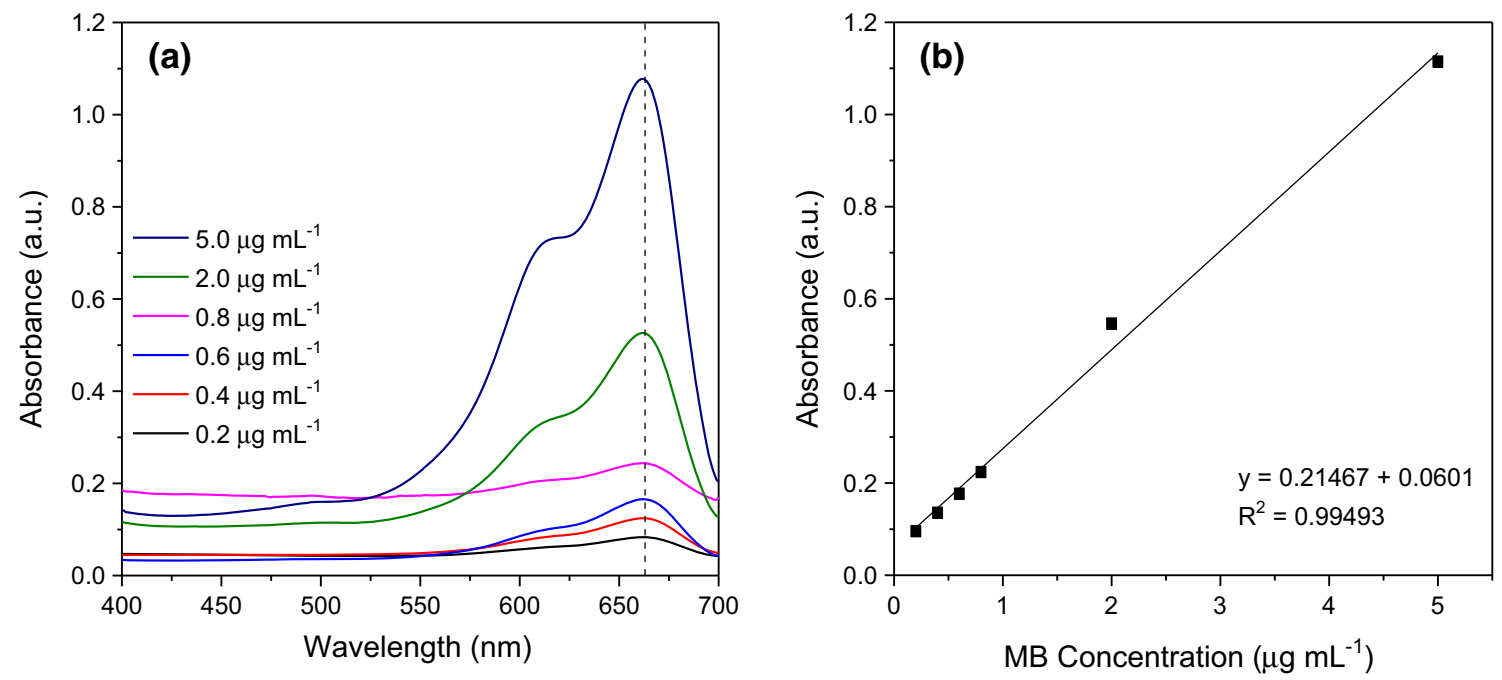

Fig. 6 a Combined absorbance spectra of MB solutions with increasing concentrations $\left(0.2-5.0 \mu \mathrm{g} \mathrm{mL}{ }^{-1}\right)$. b Calibration curve of MB at $\lambda_{\max }=664 \mathrm{~nm}$

e.g., $\left[\mathrm{UO}_{2}\left(\mathrm{CO}_{3}\right)_{3}\right]^{4-}$ in solution, which has been previously observed to adversely impact $\mathrm{U}$ sorption for similar sorbent systems [41, 42]. Thus, it is likely that electrostatic

Table 1 Elemental analysis of graphite, GO and $\mathrm{COOH}-\mathrm{GO}$ and the quantification of carboxyl groups $(\mathrm{COOH})$ based on the $\mathrm{MB}$ assay

\begin{tabular}{|c|c|c|c|}
\hline \multirow[t]{2}{*}{ Sample } & \multicolumn{2}{|c|}{ Elemental analysis $^{\mathrm{a}}$} & \multirow[t]{2}{*}{$\mathrm{M}_{\mathrm{COOH}}\left(\mu \mathrm{mol} \mathrm{mg}{ }^{-1}\right)^{b}$} \\
\hline & $\mathrm{C}(\%)$ & $\mathrm{O}(\%)$ & \\
\hline Graphite & $97.5 \pm 0.4$ & $2.4 \pm 1.5$ & $0.0006 \pm 0.0002$ \\
\hline GO & $55.8 \pm 0.6$ & $42.6 \pm 2.4$ & $0.059 \pm 0.008$ \\
\hline COOH-GO & $75.3 \pm 0.3$ & $23.6 \pm 0.8$ & $0.103 \pm 0.003$ \\
\hline
\end{tabular}

${ }^{a}$ Values reported as mean \pm SD where $n=2$

${ }^{\mathrm{b}}$ Values reported as mean $\pm \mathrm{SD}$ where $n=5$

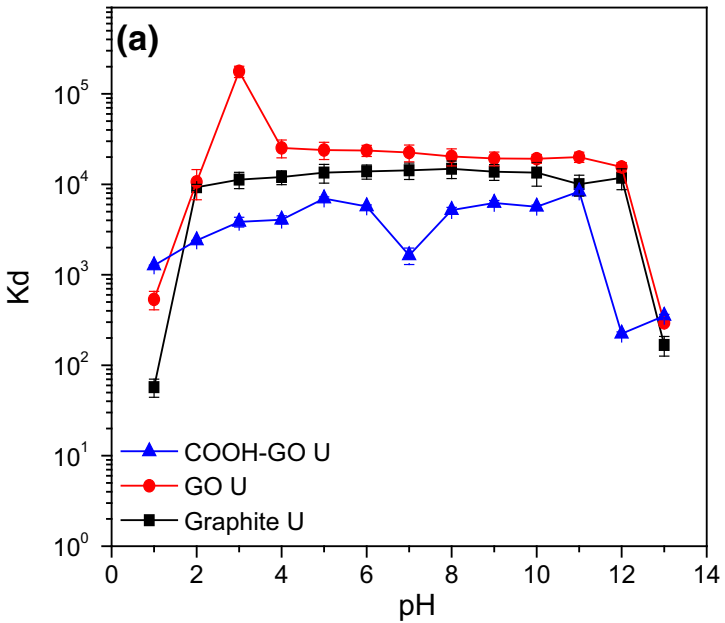

repulsion between the negative $\mathrm{U}(\mathrm{VI})$ species and the negatively charged material surface was observed at high $\mathrm{pH}$ conditions.

Overall, the optimal condition for $\mathrm{U}$ sorption was at $\mathrm{pH}$ 3, with GO being the best performing sorbent material, reporting a $K_{\mathrm{d}}$ value of $1.8 \pm 0.11 \times 10^{5} \mathrm{~mL} \mathrm{~g}^{-1}$ and $98.7 \pm 1.3 \% \mathrm{U}$ sorption. Furthermore, COOH-GO and graphite displayed $K_{\mathrm{d}}$ values of $3.8 \pm 0.17 \times 10^{3}$ and $1.1 \pm 0.04 \times 10^{4} \mathrm{~mL} \mathrm{~g}^{-1}$, respectively with the $\mathrm{U}$ sorption for $\mathrm{COOH}-\mathrm{GO}$ and graphite being $88.9 \pm 1.9$ and $94.3 \pm 1.7 \%$, respectively. These results indicate that each of the sorbent materials are suitable for the removal of uranium in solution and are consistent with the performance typically observed for commerical ion-exchange resins [43].

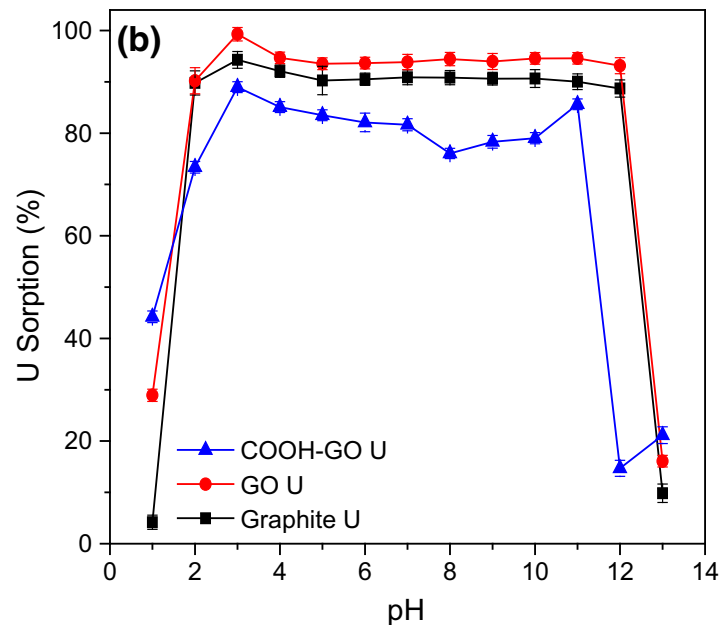

Fig. 7 a Effect of $\mathrm{pH}$ on $K_{\mathrm{d}}$ values and b $\mathrm{U}$ sorption onto graphite, GO and COOH-GO (Experimental conditions: U concentration $=10 \mu \mathrm{g} \mathrm{mL}^{-1}$, mass of adsorbent $=10 \mathrm{mg}$, volume $=10 \mathrm{~mL}, \mathrm{pH} 1-13$ ) 


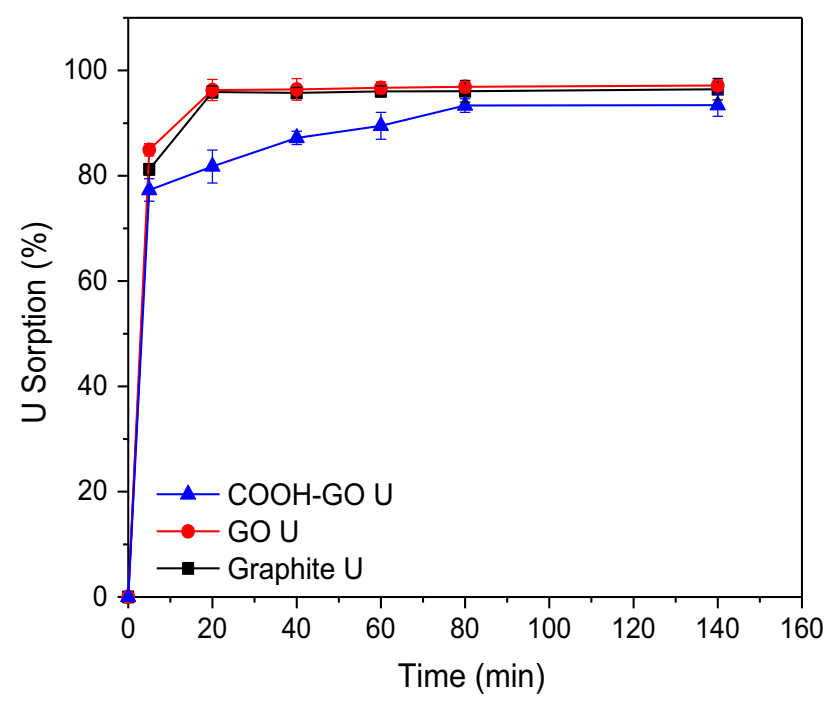

Fig. 8 Effect of contact time on $\mathrm{U}$ sorption onto graphite, GO and COOH-GO. (Experimental conditions: U concentration $=10 \mu \mathrm{g} \mathrm{mL}^{-1}$, mass of adsorbent $=10 \mathrm{mg}$, volume $=10 \mathrm{~mL}$, $\mathrm{pH} 4)$

\section{Effect of contact time}

A series of time-controlled studies were performed on graphite, $\mathrm{GO}$ and $\mathrm{COOH}-\mathrm{GO}$ from contact times of 5-140 $\mathrm{min}$ at $\mathrm{pH} 4$. Figure 8 illustrates the rapid kinetics of the sorption process for all of the materials studied, with $77.3 \pm 1.2-84.9 \pm 1.1 \% \quad \mathrm{U}$ sorption observed within $5 \mathrm{~min}$. These results compare well with those reported in the literature [17] and illustrates that the time required to reach equilibrium is $80 \mathrm{~min}$ with over $93.4 \pm 2.1 \% \mathrm{U}$ sorption attainable for COOH-GO.

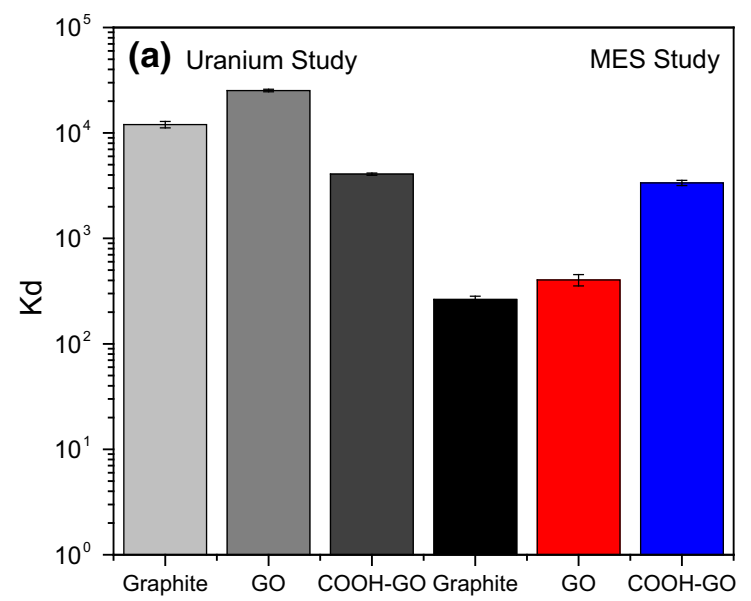

Fig. 9 a Effect on uranium selectivity by the presence of competing ions using graphite, $\mathrm{GO}$ and $\mathrm{COOH}-\mathrm{GO}$. b Sorption percentage of $\mathrm{U}$ over $\mathrm{Mg}, \mathrm{Co}, \mathrm{Zn}, \mathrm{Sr}, \mathrm{Pb}$ and $\mathrm{Th}$ onto graphite, GO and COOH-GO.

\section{Effect of competing ions}

The selective removal of $\mathrm{U}$ was investigated by exposing graphite, GO and COOH-GO to a multi-element standard (MES) solution comprising of $\mathrm{Mg}, \mathrm{Co}, \mathrm{Zn}, \mathrm{Sr}, \mathrm{Pb}$ and $\mathrm{Th}$. It was found that the performance of the graphite and GO sorbent materials were adversely impacted by the presence of competing ions (MES study) with the $K_{\mathrm{d}}$ values decreasing considerably from $1.17 \pm 0.084 \times 10^{4}$ to $2.68 \pm 0.2 \times 10^{2} \mathrm{~mL} \mathrm{~g}^{-1}$ for graphite (Fig. 9a). For GO, the $K_{\mathrm{d}}$ values decreased from $2.4 \pm 0.07 \times 10^{4}$ to $3.97 \pm 0.5 \times 10^{2} \mathrm{~mL} \mathrm{~g} \mathrm{~g}^{-1}$, respectively.

In contrast, it was seen that COOH-GO was the only sorbent material to consistently retain $\mathrm{U}$. The reported $K_{\mathrm{d}}$ values for $\mathrm{COOH}-\mathrm{GO}$ remained steady, decreasing from $4.11 \pm 0.1 \times 10^{3}$ to $3.72 \pm 0.19 \times 10^{3} \mathrm{~mL} \mathrm{~g}^{-1}$ after competing ions had been introduced into aqueous solution. This indicates that the presence of carboxyl groups on the surface of the $\mathrm{COOH}-\mathrm{GO}$ material may influence selectivity towards $\mathrm{U}$ [44].

The effect on $\mathrm{U}$ sorption (\%) by the presence of competing ions was also determined. Figure $9 \mathrm{~b}$ reveals that $\mathrm{COOH}-\mathrm{GO}$ has a higher selectivity towards the actinides present in the multi-element tracer solutions with over $65.9 \pm 2.7 \%$ of $\mathrm{U}$ retained in comparison to $38.9 \pm 1.2 \%$ for $\mathrm{GO}$ and $25.1 \pm 1.9 \%$ for graphite. While, Th was consisitently retained by both $\mathrm{GO}$ and $\mathrm{COOH}-\mathrm{GO}$ at over $99.8 \%$, which is in agreement with previously published studies $[45,46]$. As a result, it can be seen that the consistently high $K_{\mathrm{d}}$ and actinide sorption (\%) values shown by $\mathrm{COOH}-\mathrm{GO}$ makes it a promising sorbent material for selectively removing $\mathrm{U}$ from contaminated aqueous nuclear waste.

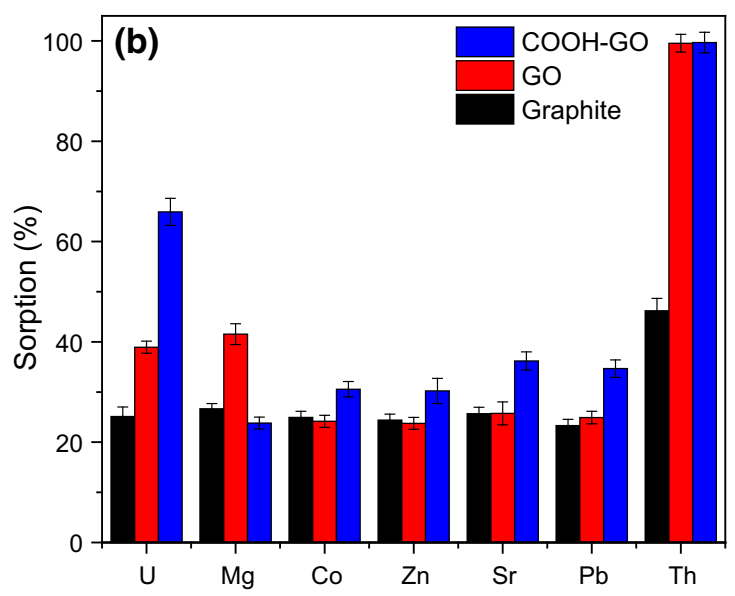

(Experimental conditions: $\mathrm{U}$ concentration $=50 \mu \mathrm{g} \mathrm{mL}{ }^{-1}$, mass of adsorbent $=10 \mathrm{mg}$, volume $=10 \mathrm{~mL}, \mathrm{pH} 4)$ 


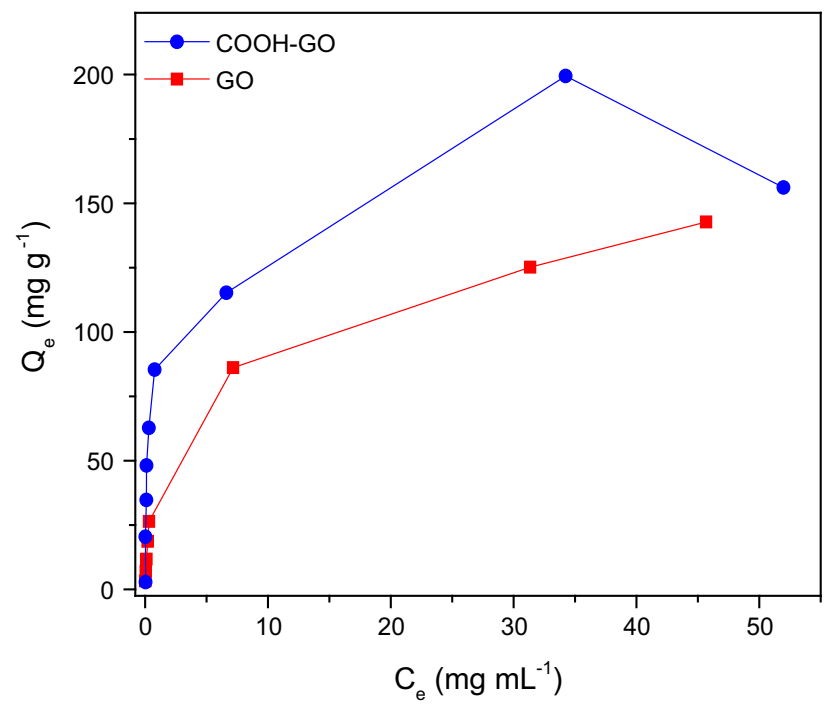

Fig. $10 \mathrm{U}$ sorption isotherm for GO and COOH-GO. (Experimental conditions: $\mathrm{U}$ concentration $=0.1-60 \mathrm{mg} \mathrm{mL}^{-1}$, mass of adsorbent $=10 \mathrm{mg}$, volume $=10 \mathrm{~mL}, \mathrm{pH} 4)$

\section{Sorption isotherms}

Sorption isotherms of GO and COOH-GO (Fig. 10) were also investigated by varying the $\mathrm{U}$ concentration from 0.1 to $60 \mathrm{mg} \mathrm{mL}^{-1}$ and determining the subsequent $\mathrm{U}$ capacity. These results were further analysed and characterised by plotting Langmuir and Freundlich isotherm models as depicted in Figs. S1 and S2. It was found from these plots that the Langmuir isotherm model fits the sorption data best. This implies that $\mathrm{U}$ sorption by $\mathrm{GO}$ and $\mathrm{COOH}-\mathrm{GO}$ occurs mainly by the formation of a monolayer of $U$ on the sorbent material [13].
Table 2 shows that the maximum sorption capacity $\left(Q_{\max }\right)$ of $\mathrm{GO}$ and $\mathrm{COOH}-\mathrm{GO}$ at $\mathrm{pH} 4$ were 142.25 and $169.20 \mathrm{mg} \mathrm{g}^{-1}$, respectively. The capacities obtained demonstrate that $\mathrm{COOH}-\mathrm{GO}$ is more effective in extracting $\mathrm{U}$ from solution than GO and the results attained are comparable to those typically observed in GO-based sorbent materials (Table 3 ). Moreover, the $Q_{\max }$ value for GO and $\mathrm{COOH}-\mathrm{GO}$ are considerably higher than those observed for other common sorbent materials such as carbon nanotubes and activated carbon.

\section{Conclusions}

This study demonstrates the capabilities of carboxyl-functionalised graphene oxide (COOH-GO) sorbent materials for selectively removing uranium from aqueous solution. The distribution coefficient is considerably higher than that observed for graphene oxide (GO) and graphite, with a value of $3.72 \pm 0.19 \times 10^{3} \mathrm{~mL} \mathrm{~g}^{-1}$ under optimal $\mathrm{pH}$ conditions. Morever, COOH-GO has a higher sorption capacity for $\mathrm{U}\left(Q_{\max }=169.20 \mathrm{mg} \mathrm{g}^{-1}\right)$ and shows a greater selectivity towards $U$ with $65.9 \pm 2.7 \%$ retained in the presence of competing ions in comparison to the $38.9 \pm 1.2 \%$ observed for GO. These enhanced values are likely due to the effect of the presence of selective surface groups, such as, carboxyls. Surface functionalisation analysis of the sorbent materials was performed by FTIR, Raman, TGA and MB colourimetric techniques. The results collected confirmed that sample preparation via the modified Hummers method and chloroacetic acid/ $\mathrm{NaOH}$ treatment lead to a greater abundance of $\mathrm{COOH}$ surface groups being present on $\mathrm{GO}$ and $\mathrm{COOH}-\mathrm{GO}$.
Table 2 The parameters for the Langmuir and Freundlich isotherm models of $\mathrm{U}$ sorption onto $\mathrm{GO}$ and $\mathrm{COOH}-\mathrm{GO}$

\begin{tabular}{llllllll}
\hline Sample & Langmuir & \multicolumn{5}{l}{ Freundlich } \\
\cline { 2 - 3 } & $Q_{\max }\left(\mathrm{mg} \mathrm{g}^{-1}\right)$ & $K_{\mathrm{L}}\left(\mathrm{mL} \mathrm{mg}^{-1}\right)$ & $R^{2}$ & & $K_{\mathrm{F}}\left(\mathrm{mL} \mathrm{mg}^{-1}\right)$ & $n$ & $R^{2}$ \\
\hline GO & 142.25 & 0.527 & 0.9913 & 4.856 & 1.823 & 0.9125 \\
COOH-GO & 169.20 & 1.310 & 0.9809 & 6.384 & 3.800 & 0.9299 \\
\hline
\end{tabular}

Table 3 Comparison of the $\mathrm{U}$ sorption capacities of $\mathrm{GO}$ and $\mathrm{COOH}-\mathrm{GO}$ with other sorbent materials

\begin{tabular}{|c|c|c|c|}
\hline Sorbents & Experimental conditions & $Q_{\max }\left(\mathrm{mg} \mathrm{g}^{-1}\right)$ & Reference \\
\hline $\mathrm{COOH}-\mathrm{GO}$ & $\mathrm{pH}=4, T=293 \mathrm{~K}$, equilibrium time $(\mathrm{min})=80$ & 169.2 & This study \\
\hline GO & $\mathrm{pH}=4, T=293 \mathrm{~K}$, equilibrium time $(\min )=80$ & 142.3 & This study \\
\hline GO & $\mathrm{pH}=5, T=293 \mathrm{~K}$, equilibrium time $(\min )=60$ & 122.4 & [47] \\
\hline Reduced GO & $\mathrm{pH}=4, T=293 \mathrm{~K}$, equilibrium time $(\min )=\mathrm{n} / \mathrm{a}$ & 74.1 & [39] \\
\hline Cyclodextrin-modified GO & $\mathrm{pH}=5, T=288 \mathrm{~K}$, equilibrium time $(\min )=\mathrm{n} / \mathrm{a}$ & 97.3 & [48] \\
\hline Multi-walled carbon nanotubes (MWCNTs) & $\mathrm{pH}=5, T=318 \mathrm{~K}$, equilibrium time $(\min )=60$ & 39.5 & [49] \\
\hline Activated carbon & $\mathrm{pH}=3, T=293 \mathrm{~K}$, equilibrium time $(\min )=180$ & 28.3 & {$[50]$} \\
\hline Silica-coated $\mathrm{Fe}_{3} \mathrm{O}_{4}$ nanoparticles & $\mathrm{pH}=6, T=293 \mathrm{~K}$, equilibrium time $(\min )=180$ & 52.4 & {$[51]$} \\
\hline
\end{tabular}


Future work will involve the completion of reusability studies in real sample matrices and desorption studies to test the efficiency of $\mathrm{COOH}-\mathrm{GO}$. It is believed these additional studies will prove to be beneficial in further demonstrating the suitability of this sorbent material for selective actinide removal from aqueous solutions.

Acknowledgements HM acknowledges financial support in the form of an iCASE studentship from the Engineering and Physical Sciences Research Council (EPSRC) awarded to the National Physical Laboratory and the University of Surrey. PHR acknowledges partial support from the Science and Technology Facilities Council (STFC, grant ST/L005743/1) and the National Measurement Office.

Open Access This article is distributed under the terms of the Creative Commons Attribution 4.0 International License (http://crea tivecommons.org/licenses/by/4.0/), which permits unrestricted use, distribution, and reproduction in any medium, provided you give appropriate credit to the original author(s) and the source, provide a link to the Creative Commons license, and indicate if changes were made.

\section{References}

1. Holden NE (1981) The uranium half-lives: a critical review. Brookhaven National Laboratory Report, BNL-NCS-51320

2. Rosenberg E, Pinson G, Tsosie R (2016) Uranium remediation by ion exchange and sorption methods: a critical review. Johnson Matthey Technol Rev 60:59-77

3. Bhalara PD, Punetha D, Balasubramanian K (2014) A review of potential remediation techniques for uranium(VI) ion retrieval from contaminated aqueous environment. J Environ Chem Eng 2:1621-1634

4. Department for Environment, Food and Rural Affairs (DEFRA) (2011) Guidance on the scope of and exemptions from the radioactive substances legislation in the UK (England and Wales)

5. Davies P, Walton S, Ashley S, Tzalenchuk A, Williams C, Wiper $P$ (2017) The potential applications of graphene (and related compounds) relevant to the NDA's decommissioning mission, NS4145-500-005, Issue 3

6. Fesenko S, Jacob P, Ulanovsky A, Chupov A, Bogdevich I, Sanzharova N, Kaskparov V, Panov A, Zhuchenka Y (2013) Justification of remediation strategies in the long term after the Chernobyl accident. J Environ Radioact 119:39-47

7. Maiti TC, Kaye JH, Kozelisky AE (1992) Sequential separation of $\mathrm{Pu}, \mathrm{Np}, \mathrm{U}$ and $\mathrm{Am}$ from highly radioactive Handford waste by ion-exchange methods. J Radioanal Nucl Chem 161:533-540

8. Duff MC, Coughlin JU, Hunter DB (2002) Uranium co-precipitation with iron oxide minerals. Geochim Cosmochim Acta 66:3533-3547

9. Kumar JR, Kim J-S, Lee J-Y, Yoon H-S (2011) A brief review on solvent extraction of uranium from acidic solutions. Sep Purif Rev 40:77-125

10. Choppin GR, Morgenstern A (2000) Radionuclide separations in radioactive waste disposal. J Radioanal Nucl Chem 243:45

11. Katsoyiannis IA, Zouboulis AI (2013) Removal of uranium from contaminated drinking water: a mini review of available treatment methods. Desalin Water Treat 51:2915-2925

12. Yu S, Wang X, Tan X, Wang X (2015) Sorption of radionuclides from aqueous systems onto graphene oxide-based materials: a review. Inorg Chem Front 2:593-612
13. Romanchuk AY, Slesarev AS, Kalmykov SN, Kosynkin DV, Tour JM (2013) Graphene oxide for effective radionuclide removal. Phys Chem Chem Phys 15:2321-2327

14. Wang S, Li L, Zhang X, Qiu J, Weeks BL (2013) Reduced graphene oxide-linked stacked polymer forests for high energydensity supercapacitor. Nano Energy 2:628-635

15. Lonkar SP, Deshmukh YS, Abdala AA (2015) Recent advances in chemical modifications of graphene. Nano Res 8:1039-1074

16. Wu Q-Y, Lan J-H, Wang C-Z, Xiao C-L, Zhao Y-L, Wei Y-Z, Chai Z-F, Shi W-Q (2014) Understanding the bonding nature of uranyl ion and functionalized graphene: a theoretical study. J Phys Chem A 118:2149-2158

17. Li Z, Chen F, Yuan L, Liu Y, Zhao Y, Chai Z, Shi W (2012) Uranium(VI) adsorption on graphene oxide nanosheets from aqueous solutions. Chem Eng J 210:539-546

18. Wang F, Li H, Liu Q, Li Z, Li R, Zhang H, Liu L, Emelchenko GA, Wang J (2016) A graphene oxide/amidoxime hydrogel for enhanced uranium capture. Sci Rep 6:19367

19. Hummers WS, Offeman RE (1958) Preparation of graphitic oxide. J Am Chem Soc 80:1339

20. Jasim DA, Lozano N, Kostarelos K (2016) Synthesis of fewlayered, high-purity graphene oxide sheets from different graphite sources for biology. 2D Mater 3:014006

21. Li D, Müller MB, Gilje S, Kaner RB, Wallace GG (2008) Processable aqueous dispersions of graphene nanosheets. Nat Nano 3:101-105

22. Yu S, Liu J, Zhu W, Hu Z-T, Lim T-T, Yan X (2015) Facile room-temperature synthesis of carboxylated graphene oxidecopper sulfide nanocomposite with high photodegradation and disinfection activities under solar light irradiation. Sci Rep 5:16369

23. Sun X, Liu Z, Welsher K, Robinson JT, Goodwin A, Zaric S, Dai $\mathrm{H}$ (2008) Nano-graphene oxide for cellular imaging and drug delivery. Nano Res 1:203-212

24. Imani R, Emami SH, Faghihi S (2015) Nano-graphene oxide carboxylation for efficient bioconjugation applications: a quantitative optimization approach. J Nanopart Res 17:88

25. Nguyen KC (2012) Quantitative analysis of COOH-terminated alkanethiol SAMs on gold nanoparticle surfaces. Adv Nat Sci Nanosci Nanotechnol 3:04500

26. Russell BC, Croudace IW, Warwick PE (2015) Determination of ${ }^{135} \mathrm{Cs}$ and ${ }^{137} \mathrm{Cs}$ in environmental samples: a review. Anal Chim Acta 890:7-20

27. Marcano DC, Kosynkin DV, Berlin MJ, Sinitskii A, Sun Z, Slesarev A, Alemany LB, Lu W, Tour JM (2010) Improved synthesis of graphene oxide. ACS Nano 4:4806-4814

28. Dreyer DR, Park S, Bielawski CW, Ruoff RS (2010) The chemistry of graphene oxide. Chem Soc Rev 39:228-240

29. Ferrari AC, Basko DM (2013) Raman spectroscopy as a versatile tool for studying the properties of graphene. Nat Nano 8:235-246

30. Bokobza L, Bruneel J-L, Couzi M (2014) Raman spectroscopy as a tool for the analysis of carbon-based materials (highly oriented pyrolitic graphite, multilayer graphene and multiwall carbon nanotubes) and of some of their elastomeric composites. Vib Spectrosc 74:57-63

31. Wang G, Yang J, Park J, Gou X, Wang B, Liu H, Yao J (2008) Facile synthesis and characterization of graphene nanosheets. J Phys Chem C 112:8192-8195

32. Cançado LG, Jorio A, Ferreira EHM, Stavale F, Achete CA, Capaz RB, Moutinho MVO, Lombardo A, Kulmala T, Ferrari AC (2011) Quantifying defects in graphene via Raman spectroscopy at different excitation energies. Nano Lett 11:3190-3196

33. Ni Z, Wang Y, Yu T, Shen Z (2008) Raman spectroscopy and imaging of graphene. Nano Res 1:273-291 
34. Jiang W, Nadeau G, Zaghib K, Kinoshita K (2000) Thermal analysis of the oxidation of natural graphite-effect of particle size. Thermochim Acta 351:85-93

35. Oh YJ, Yoo JJ, Kim YI, Yoon JK, Yoon HN, Kim JH, Park SB (2014) Oxygen functional groups and electrochemical capacitive behavior of incompletely reduced graphene oxides as a thin-film electrode of supercapacitor. Electrochim Acta 116:118-128

36. El-Khodary S, El-Enany G, El-Okr M, Ibrahim M (2014) Preparation and characterization of microwave reduced graphite oxide for high-performance supercapacitors. Electrochim Acta 150:269-278

37. Li J, Liu D, Li B, Wang J, Han S, Liu L, Wei H (2014) A bioinspired nacre-like layered hybrid structure of calcium carbonate under the control of carboxyl graphene. Cryst Eng Comm 17:520-525

38. Xie Y, Helvenston EM, Shuller-Nickles LC, Powell BA (2016) Surface complexation modeling of Eu(III) and U(VI) interactions with graphene oxide. Environ Sci Technol 50:1821-1827

39. Sun Y, Yang S, Chen Y, Ding C, Cheng W, Wang X (2015) Adsorption and desorption of U(VI) on functionalized graphene oxides: a combined experimental and theoretical study. Environ Sci Technol 49:4255-4262

40. Ding Z, Ma H, Chen Y (2014) Interaction of graphene oxide with human serum albumin and its mechanism. RSC Adv 4:55290-55295

41. Ivanov P, Griffiths T, Bryan ND, Bozhikov G, Dmitriev S (2012) The effect of humic acid on uranyl sorption onto bentonite at trace uranium levels. J Environ Monit 14:2968-2975

42. Wang Y, Liu X, Huang Y, Hayat T, Alsaedi A, Li J (2017) Interaction mechanisms of $\mathrm{U}(\mathrm{VI})$ and graphene oxide from the perspective of particle size distribution. J Radioanal Nucl Chem 311:209-217

43. Ladeira A, Renato Gonçalves C (2007) Influence of anionic species on uranium separation from acid mine water using strong base resins. J Hazard Mater 148:499-504
44. Franczyk TS, Czerwinski KR, Raymond KN (1992) Stereognostic coordination chemistry. 1 . The design and synthesis of chelators for the uranyl ion. J Am Chem Soc 114:8138-8146

45. Li F, Yang Z, Weng H, Chen G, Lin M, Zhao C (2018) High efficient separation of U(VI) and Th(IV) from rare earth elements in strong acidic solution by selective sorption on phenanthroline diamide functionalized graphene oxide. Chem Eng J 332:340-350

46. Pan N, Li L, Ding J, Li S, Wang R, Jin Y, Wang X, Xia C (2016) Preparation of graphene oxide-manganese dioxide for highly efficient adsorption and separation of $\mathrm{Th}(\mathrm{IV}) / \mathrm{U}(\mathrm{VI})$. J Hazard Mater 309:107-115

47. Liu S, Li S, Zhang H, Wu L, Sun L, Ma J (2016) Removal of uranium (VI) from aqueous solution using graphene oxide and its amine-functionalized composite. J Radioanal Nucl Chem 309:607-614

48. Song W, Shao D, Lu S, Wang X (2014) Simultaneous removal of uranium and humic acid by cyclodextrin modified graphene oxide nanosheets. Sci China Chem 57:1291-1299

49. Fasfous II, Dawoud JN (2012) Uranium (VI) sorption by multiwalled carbon nanotubes from aqueous solution. Appl Surf Sci 259:433-440

50. Mellah A, Chegrouche S, Barkat M (2016) The removal of uranium(VI) from aqueous solutions onto activated carbon: kinetic and thermodynamic investigations. J Colloid Interface Sci 296:434-441

51. Fan FL, Qin Z, Bai J, Rong W-D, Fan F-Y, Tian W, Wu X-L, Wang Y, Zhao L (2012) Rapid removal of uranium from aqueous solutions using magnetic $\mathrm{Fe}_{3} \mathrm{O}_{4} @ \mathrm{SiO}_{2}$ composite particles. J Environ Radioact 106:40-46 